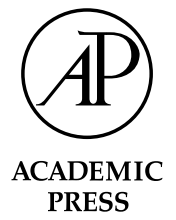

\title{
Inflammatory mediators expressed in human islets of Langerhans: implications for islet transplantation ${ }^{\text {is }}$, 论岤
}

\author{
Ulrika Johansson, ${ }^{\mathrm{a}, *, 1}$ Annika Olsson, ${ }^{\mathrm{a}, 1}$ Susanne Gabrielsson, ${ }^{\mathrm{b}}$ \\ Bo Nilsson, ${ }^{\mathrm{a}}$ and Olle Korsgren ${ }^{\mathrm{a}}$ \\ a Department of Clinical Immunology, The Rudbeck Laboratory, Uppsala University C11, Uppsala SE-751 85, Sweden \\ ${ }^{\mathrm{b}}$ Unit of Clinical Allergy Research, Department of Medicine, Karolinska Institute and hospital, Sweden
}

Received 9 July 2003

\begin{abstract}
Expression of immune modulating mediators in human Islets of Langerhans could have important implications for development of autoimmunity in type 1 diabetes and influence the outcome of clinical islet transplantation. Islets obtained from five donors were analyzed at various times after isolation using cDNA array technology. The Atlas Human Cytokine/Receptor and Hematology/ Immunology nylon membranes representing 268 genes and 406, respectively, were used and the relative expression of each gene analyzed. Of the 51 gene products identified, high mRNA expression of MCP-1, MIF, VEGF, and thymosin $\beta-10$ was detected in all islet samples. IL-8, IL-1- $\beta$, IL-5R, and INF- $\gamma$ antagonist were expressed in islets cultured for 2 days. IL-2R was expressed in islets cultured for more than 6 days. In conclusion, several inflammatory mediators were expressed in isolated islets, particularly at an early stage after isolation, indicating that a few days of culture could be beneficial for the outcome of islet transplantation.
\end{abstract}

(C) 2003 Elsevier Inc. All rights reserved.

Keywords: cDNA array; Islets of Langerhans; Cytokines; Cytokine receptors; Human

\footnotetext{
This study was supported by grants from the Swedish Medical Research Council (16P-13568 and 16X-12219), Åke Wiberg Foundation, Nordic Insulin Fund, Torsten and Ragnar Söderbergs Foundation, Family Ernfors Fund, Barn Diabetes Fonden, Göran Gustafsson Foundation, Swedish Diabetes Association, Juvenile Diabetes Foundation International and the Knut and Alice Wallenberg Foundation.

动 mentary DNA; RNA, ribonucleic acid; Rnase, ribonuclease; Dnase, deoxyribonuclease; mRNA, messenger RNA; IBMIR, instant bloodmediated inflammatory reaction; TF, tissue factor; MCP-1, monocyte chemoattractant protein-1; TGF $\beta$, transforming growth factor $\beta$; MIF, macrophage migration inhibitory factor; IL, interleukin; INF, interferon; PBS, phosphate-buffered saline; TUBA1, brain-specific tubulin $\alpha 1$ subunit; HLAC, HLA class I histocompatibility antigen C$4 \alpha$ subunit; ACTB, cytoplasmic $\beta$-actin; RPL13A, 23-kDa highly basic protein, $60 \mathrm{~S}$ ribosomal protein L13A; $\beta$-cells, beta cells; CPM, counts per minute; ICU, intensive care unit; T-cell, thymus gland lymphocyte (cell); VEGF, vascular endothelial growth factor; TB 4, thymosin $\beta-4$; TB10, thymosin $\beta-10$; SEM, standard error of mean.

${ }^{*}$ Corresponding author. Fax: +46-18-611-02-22.

E-mail address: Ulrika.Johansson@klinimm.uu.se (U. Johansson).

${ }^{1}$ Authors contributed equally to the work.
}

We have recently described an inflammatory reaction, which occurs when isolated Islets of Langerhans come in contact with fresh human blood at the time of intraportal infusion. This process, described as an instant blood mediated inflammatory reaction (IBMIR), may account for the apparent need of islets isolated from multiple donors to achieve insulin independence after islet transplantation [1]. Isolated human islets synthesize and secrete Tissue Factor (TF), a member of the cytokine receptor superfamily type- 1 . TF released from the islets at the time of transplantation seems to be the main trigger of IBMIR [2]. This illustrates the importance of the interplay between the tissue to be transplanted and the immune response awakened in the recipient. Endogenous expression of some immune modulating proteins, monocyte chemoattractant protein-1, MCP-1, transforming growth factor $\beta$, TGF $\beta$ [3], and macrophage migration inhibitory factor, MIF $[9,10]$, in islets has already been reported. Expression of these as well as other so far unknown factors with immune modulating capacity could markedly influence the outcome of 
intraportal islet transplantation. Likewise, expression of inflammatory mediators in the islets situated in the native pancreas could have an important role in the development of autoimmunity in type 1 diabetes.

State-of-the-art in clinical islet transplantation includes the utilization of islets isolated from several donors. The islet preparations are only to some extent characterized. To discriminate between endocrine and non-endocrine cells dithiazone-staining is commonly applied. Using this technique the purity of the islet preparation is usually reported to be in the range of 70 $95 \%$. However, using immunohistochemical techniques the purity is markedly lower and figures in the range of $20-50 \%$ are usually reported $[1,4]$. Exocrine cells and duct cells constitute a major part of the non-endocrine cells, however, a large fraction of these non-endocrine cells is of unknown origin [1]. Attempts to further purify the islet preparations usually fail due to a marked loss of the total number of insulin-producing cells. Irrespectively of their origin all cells within an islet preparation may contribute to the immune response induced after transplantation.

Expression of inflammatory mediators in the Islets of Langerhans could have important implications in the development of autoimmunity in type 1 diabetes as well as after clinical islet transplantation. Recently, nitrocellulose-based cDNA arrays were introduced as a focused and reproducible analysis of gene expression in human islets [5]. The aim of the present study was to screen isolated human Islets of Langerhans for mRNA expression of genes with a potential to induce or modulate an immune response. Specifically, the Atlas Human Cytokine/Receptor and Hematology/Immunology nylon membranes representing 268 genes and 406, respectively, were used and the relative expression of each gene analyzed.

\section{Materials and methods}

Islets of Langerhans isolation and culture. Human Islets of Langerhans were isolated using a modification of the semi-automated digestion-filtration method [6-8], followed by purification on a continuous density gradient in a refrigerated COBE 2991 centrifuge (COBE Blood Component Technology, Lakewood, CO). The pancreata were obtained from normoglycemic donors after appropriate consent for multiorgan donation. We used organs from five donors, age 40-75 years, two female and three men with body weight $78.6 \pm 3.5 \mathrm{~kg}$. The cold-ischemic time ranged between 4 and $8 \mathrm{~h}$.

The purity and quality of the islet preparations fulfilled our release criteria for clinical transplantation; however, the total islet volume was too low for clinical transplantation, total number of islets $257,000 \pm 46,300$ IEQ. The islet preparations were placed in untreated petri dishes Sterilin (Tamro Med. Lab. AB) and kept at $37^{\circ} \mathrm{C}$ in an atmosphere of $5 \% \mathrm{CO}_{2}$ in humidified air in culture medium, CMRL 1066 (Gibco-BRL, Invitrogen) supplemented with $10 \mathrm{mM}$ nicotinamide (Sigma Chemicals), $10 \mathrm{mM}$ Hepes buffer (Gibco-BRL, Invitrogen), $\quad 0.25 \mu \mathrm{g} / \mathrm{ml}$ fungizone (Gibco-BRL, Invitrogen), $50 \mu \mathrm{g} / \mathrm{ml}$ gentamicin (Gibco-BRL, Invitrogen), $2 \mathrm{mM}$ L-glutamine (Gibco-BRL,
Invitrogen), $10 \mu \mathrm{g} / \mathrm{ml}$ ciprofloxacin (Bayer), and 10\% (v/v) heat-inactivated human serum. The islets were cultured for 1-11 days and medium was changed every second day.

Quality tests. The volume and purity of the islets varied and was determined by microscope characterization and sizing on a grid after staining with diphenylthiocarbazone. The viability of the islets was evaluated in a dynamic perfusion system. Islets were challenged with two glucose concentrations (initially in $1.67 \mathrm{mmol} / \mathrm{L}$ and then in $16.7 \mathrm{mmol} / \mathrm{L}$ glucose). Fractions were collected with 6-min interval during $120 \mathrm{~min}$ and the insulin content determined by ELISA (Mercodia, Uppsala, Sweden). The stimulation index was calculated by dividing the amount of insulin released per minute in $16.7 \mathrm{mM}$ glucose by the amount of insulin released per minute in $1.67 \mathrm{mM}$ glucose. Insulin/DNA ratio and $\mathrm{pmol} / \mathrm{L} / \mu \mathrm{g}$ were measured as previously described [9].

Oligonucleotide array. At days 2-11 after isolation, islets were immersed in RNA later and frozen in $-70^{\circ} \mathrm{C}$ for later total RNA preparation. Total RNA from islet samples were prepared by washing once with PBS to free islets from RNA later and then using NucleoSpin RNA II Kit (BD Clontech, Palo Alto, CA) according to the manufacturer's instructions. To avoid unspecific degradation of RNA, anti-RNase (Ambion, Austin, TX) was added to the column during the DNase treatment. Total RNA yield was calculated by measuring the optical density at $260 \mathrm{~nm}$. Radioactively labelled probes were produced from 2.0 to $12.0 \mu \mathrm{g} / \mathrm{ml}$ per islet sample, using the Atlas Pure Total RNA labelling system (BD Clontech, Palo Alto, CA) according to the manufacturer's instructions. The probes were then hybridized overnight at $68^{\circ} \mathrm{C}$ to the Atlas Human Cytokine/Receptor nylon membrane or the Atlas Human Hematology/Immunology nylon membrane (BD Clontech, Palo Alto, CA) representing 268 and 406 genes in duplicates, including nine housekeeping genes and controls for genomic contamination.

Analysis of gene expression. Visualizations were preformed using Fuji BAS 1800 I IR after 1-3 days of exposure. Files were processed and scanned using Image Guage and AtlasImage 2.0 (BD Clontech, Palo Alto, CA) to finalize the analysis. After subtracting background values for each membrane, expression of the different genes was calculated and related to the mean intensity of five housekeeping genes (brain-specific tubulin $\alpha 1$ subunit (TUBA1), HLA class I histocompatibility antigen C-4 $\alpha$ subunit (HLAC), cytoplasmic $\beta$-actin (ACTB), 23-kDa highly basic protein, 60S ribosomal protein L13A (RPL13A), and $40 \mathrm{~S}$ ribosomal protein S9) on the same array. The threshold for genuine gene expression was set, according to the manufacturer's instruction, to an adjusted intensity (intensity minus the background) of at least three times the background value. For selection of housekeeping genes, we used the global sum normalization. The other housekeeping genes present on the membranes ubiquitin, phospholipase A2, hypoxanthine-guanine phosphoribosyltransferase (HPRT), and liver glyceraldehyde 3-phosphate dehydrogenase (GAPDH) were in preliminary experiments showing greater variability than the ones used (data not shown).

Statistical analysis. Data are presented as means \pm SEM.

\section{Results}

\section{Quality tests}

The purity of the human islet preparations was between $50 \%$ and $80 \%(66 \pm 13.4 \%)$. The insulin content was $255.5 \pm 51.0 \mathrm{pmol} / \mathrm{L} / \mu \mathrm{g}$ DNA. Specific function was evaluated using a dynamic perfusion system (Fig. 1) where insulin release was increased when the concentration of glucose in the perfusate was raised. Stimulation index was $17.2 \pm 8.4$. 


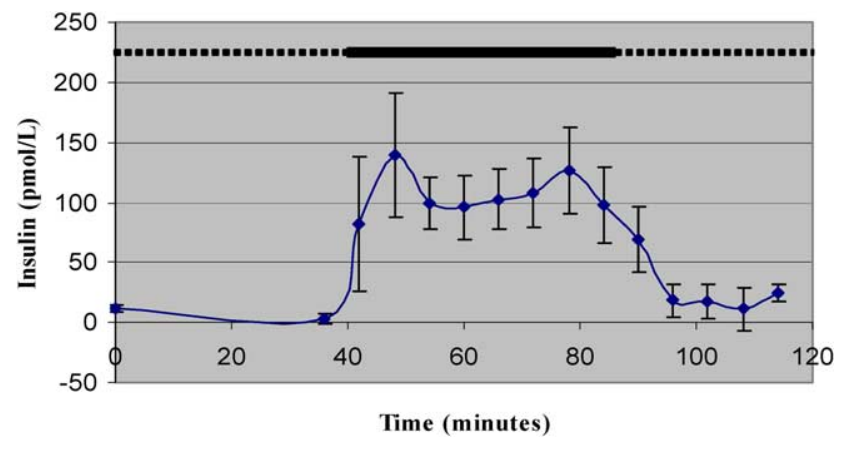

Fig. 1. Dynamic insulin release. Isolated islets $(n=20)$ were perfused with 1.67 (dotted line) or 16.7 (bold line) $\mathrm{mM}$ glucose as indicated in the figure. Data are presented as means \pm SEM, $n=4$.

\section{Array analysis}

Of the 269 genes represented on the Atlas Human Cytokine/Receptor array, 51 genes excluding housekeeping genes were expressed in isolated human pancreatic islets with only small variations between the five different islet preparations.

Only clinical grade islet preparations were used, but an mRNA contribution from non-endocrine cells cannot be excluded. Of the 51 identified gene products, mRNA of monocyte chemoattractant protein-1 (MCP1), migration inhibitor factor (MIF), VEGF, and thymosin $\beta-10$ were detected in all islet samples. Gene expressions detected in the different islet preparations are presented in Table 1.

We also analyzed inflammatory gene expression using Atlas Human Hematology/Immunology Array. Essentially, the results confirmed the gene expression detected using the Atlas Human Cytokine/Receptor kit and no major additional gene products were identified (data not shown).

\section{Discussion}

Isolated human pancreatic islets were screened for inflammatory and cytokine genes that could be involved in the initiation of the immune response induced after clinical islet transplantation. Surprisingly, we found that isolated human islets express many genes involved in the generation of inflammatory responses. The expression of several of these genes has not previously been reported in human islets. The inflammatory mediators detected may also be involved in the autoimmune destruction of the $\beta$-cells in type 1 diabetes mellitus.

Recent advances in nucleic acid biotechnology have led to the development of DNA arrays. Using this technique, mRNA expression analysis of hundreds to ten thousands of genes can be performed simultaneously in one experiment [10]. Since the amount of RNA required for analysis of differential gene expression is relatively large, many reports have utilized cell lines rather than primary islets $[11,12]$. It should also be emphasized that the variation in absolute transcript numbers between different cytokines studied does not necessarily reflect the importance of a specific cytokine. Disparities in mRNA degradation, translation efficiency, and receptor expression and affinity for all cytokines assayed are not fully characterized.

The choice of studying the cytokines at mRNA level instead of protein level was based on the possibility to quantify the gene expression as offered by the array assay. Also, for small tissue samples, such as isolated islets, it is difficult to detect hundreds of different proteins.

It could also be argued that macrophages and endothelial cells present in the islet preparations could be the cause of the gene expression found. However, a contribution from these cells present in low frequency seems unlikely due to the fact that we have not amplified our cDNA samples. Finally, from a clinical perspective the type of cell responsible for the expression is of less importance, since all cells within an islet preparation will contribute to the immune response induced. It seems unlikely that there is a constitutive gene expression of all these pro-inflammatory genes in the Islets of Langerhans. If so, this expression must be balanced with potent local inhibitors with a capacity to inhibit inflammation, since immunocompetent cells normally do not infiltrate the islets in the pancreas. These speculations are substantiated by in vitro experiments showing that inflammatory mediators like MCP-1 exert a biological effect corresponding with its level of expression [13]. If an inhibitor was present modulating the biological effect of MCP-1, no such correlation would have been seen. Therefore, it is expected that the expression of most of the pro-inflammatory genes detected in the Islets of Langerhans is induced by one or several factors directly or indirectly affecting the Islets of Langerhans. The individual differences between the donors if most likely dependent on factors such as the time at the ICU, the cause of death, by cortisol, thyroidea hormones, catecholamines, and other stress-related hormones released prior to death, warm and cold ischemia time, etc. Also, the culture conditions presently applied for human islets prior to transplantation are, due to practical reasons, far from optimal. For experimental purposes 150-200 rodent islets are usually cultured in $5 \mathrm{ml}$ of culture medium. In contrast, high-density cultures have to be applied when human islets are cultured prior to transplantation, i.e., $5000-10,000$ human islets are cultured in $10 \mathrm{ml}$ of culture media. This may induce relative hypoxia and nutrient deprivation in the core of at least the largest islets, explaining the variation in gene expression over time in culture.

Several of the genes identified encode for proteins with a powerful biological activity, e.g., IL-1 $\beta$, IL-8, 


\section{Genbank \\ Accession No.}

Growth factors, cytokines, and chemokines

Bone morphogenetic protein 1 (BMP1)

Bone morphogenetic protein 5 precursor (BMP5)

M22488

Endothelial-monocyte activating polypeptide II (EMAP II)

Fibroblast growth factor 8 (FGF8)

Granulocyte chemotactic protein 2 (GCP 2)

Macrophage-stimulating protein (MSP)

Hepatoma-derived growth factor (HDGF)

Interferon gamma antagonist

Interleukin-8 precursor (IL-8)

Macrophage inflammatory protein 2 alpha (MIP2- $\alpha$ )

Migration inhibitory factor-related protein 14 (MRP14)

Monocyte chemotactic protein 1 precursor (MCP1)

Placenta growth factors $1+2$ (PLGF1 + PLGF2)

Platelet-derived growth factor A subunit precursor (PDGFA; PDGF1)

T-cell-specific rantes protein precursor

Teratocarcinoma-derived growth factor 1 (TDGF1)

Thymosin $\beta$-10 (TMSB10; THYB10)

Vascular endothelial growth factor precursor (VEGF)

\section{Interleukins and interferons}

Interleukin-1 $\beta$ precursor (IL-1; IL1B)

Interleukin-10 precursor (IL-10)

Interleukin-11 (IL-11)

Interleukin-6 precursor (IL-6)

M60314

U10117

U36223

X78686

M74178

D16431

A25270

Y00787

X53799

X06233

M24545

X54936

X06374

M21121

M96956

M92381

M32977

K02770

M57627

M57765

X04602

Day 2

Day 2

Day 6

Day $7 \quad$ Day 11

Interleukin and interferon receptors and plasma membrane proteins

Interleukin-2 receptor alpha subunit precursor

(IL-2 receptor $\alpha$ subunit)

Interleukin-5 receptor alpha subunit precursor (IL-5R- $\alpha$ )

Neuropeptides

Neurotrophin-3 precursor (NT-3)

Plasma membrane proteins

Delta-like protein precursor (DLK)

Hormones

Renin-binding protein (RENBP; RNBP)

Ribonuclease/angiogenin inhibitor (RAI)

Other extracellular communication proteins and plasma membrane proteins

Jagged2 (JAG2)

Other extracellular communication proteins and apoptosis associated proteins

Macrophage migration inhibitory factor (MIF)

PDGF associated protein

M25639

U41745

15.5

4.7

25.5

9.9

X14454

9.7

Interferon regulatory factor 1 (IRF1)

Growth factor and chemokine receptors, other receptors and plasma membrane proteins

Neuromedin B receptor (NMBR)

M73482

D10202

Platelet-activating factor receptor (PAFR)

$\begin{array}{ll}\text { Platelet-derived growth factor receptor } \beta \text { subunit (PDGFRB) } & \text { M21616 } \\ \text { N-sam; fibroblast growth factor receptor } 1 \text { precursor (FGFR1) } & \text { M37722 }\end{array}$

Cysteine-rich fibroblast growth factor receptor

U28811

Oncogenes and tumor suppressors

Insulin-like growth factor binding protein 2 (IGFBP2)

Prohibitin (PHB)
M35410

S85655

\begin{tabular}{|c|c|}
\hline 5.3 & 14.0 \\
\hline 5.8 & $*$ \\
\hline 5.2 & 14.5 \\
\hline 4.7 & 19.7 \\
\hline 4.4 & $*$ \\
\hline 4.5 & $*$ \\
\hline * & 9.2 \\
\hline 5.4 & 12.4 \\
\hline 11.8 & 32.3 \\
\hline 7.2 & 34.2 \\
\hline$*$ & $*$ \\
\hline 74.9 & 289.4 \\
\hline 4.9 & $*$ \\
\hline 13.5 & * \\
\hline 9.3 & * \\
\hline * & $*$ \\
\hline 116.5 & 206.2 \\
\hline 28.5 & 37.9 \\
\hline
\end{tabular}

\begin{tabular}{|c|c|c|}
\hline * & * & $*$ \\
\hline * & * & \\
\hline * & * & \\
\hline * & * & \\
\hline * & * & \\
\hline * & * & \\
\hline * & $*$ & \\
\hline * & 26.5 & \\
\hline * & $*$ & \\
\hline 12.2 & 45.9 & \\
\hline 28.9 & $*$ & \\
\hline 82.4 & 202.2 & \\
\hline * & $*$ & \\
\hline * & $*$ & \\
\hline 74.0 & 108.5 & \\
\hline * & 25.7 & \\
\hline 124.8 & 331.6 & \\
\hline 14.2 & 62.4 & \\
\hline * & * & \\
\hline * & * & \\
\hline * & * & \\
\hline * & $*$ & \\
\hline
\end{tabular}

15.7

58.2

125.5

9.4

$*$

17.0

28.

264.0

$$
12.5
$$

8.5 


\begin{tabular}{|c|c|c|c|c|c|c|}
\hline & $\begin{array}{l}\text { Genbank } \\
\text { Accession No. }\end{array}$ & Day 2 & Day 2 & Day 6 & Day 7 & Day 11 \\
\hline Neurogenic locus notch protein $(\mathrm{N})$ & M99437 & * & 14.6 & * & * & * \\
\hline ERBB-3 receptor protein-tyrosine kinase precursor & M29366 & * & 19.6 & 9.4 & * & * \\
\hline \multicolumn{7}{|l|}{ Death receptors } \\
\hline Secreted apoptosis-related protein 1 (SARP1) & AF017986 & 8.5 & * & * & 31.9 & * \\
\hline Tumor necrosis factor receptor 1 (TNFR1) & M33294 & 4.0 & 13.1 & 8.1 & * & * \\
\hline CD27BP (Siva) & U82938 & 7.4 & 12.5 & 8.5 & * & * \\
\hline \multicolumn{7}{|l|}{ Intracellular transducers/effectors/modulators } \\
\hline Ephrin type-A receptor 2 precursor & M59371 & * & 9.4 & * & * & * \\
\hline Thrombin receptor (TR) & M62424 & 7.0 & * & * & * & 29.7 \\
\hline $\begin{array}{l}\text { Epithelial discoidin domain receptor } 1 \text { precursor (EDDR1; } \\
\text { DDR1) }\end{array}$ & X74979 & 13.2 & 54.3 & 25.9 & 79.2 & * \\
\hline Leukemia inhibitory factor precursor (LIF) & X13967 & 8.2 & * & * & * & * \\
\hline \multicolumn{7}{|l|}{ Inhibitors of proteases and extracellular secreted proteins } \\
\hline Glia-derived neurite-promoting factor (GDNPF) & A03911 & 4.7 & * & * & * & * \\
\hline \multicolumn{7}{|l|}{$\begin{array}{l}\text { Others involved in protein turnover, cell surface antigens } \\
\text { and plasma membrane proteins }\end{array}$} \\
\hline Basigin precursor (BSG) & L20471 & 4.3 & 10.0 & * & * & * \\
\hline $\begin{array}{l}\text { Functionally unclassified and unclassified localization } \\
\text { Leukocyte interferon-inducible peptide }\end{array}$ & X02492 & * & * & $*$ & 24.8 & * \\
\hline
\end{tabular}

Values represent adjusted intensity of gene expression after substraction of three times the background and normalization with the mean of five housekeeping genes (TUBA1, HLAC, ACTB, RPL13A, and 40S ribosomal protein S9) for each array.

${ }^{*}$ Genes undetected due to low signal or high background.

MIP-2, MCP-1, and MIF, and if expressed in vivo after transplantation it is expected that they would rapidly induce an intense inflammation and enhance subsequent specific immune response. IL-1 $\beta$ is a pro-inflammatory mediator that also has a direct cytotoxic effect on rodent $\beta$-cells in vitro $[14,15]$. Biologically active MCP-1 is produced and secreted by human islets and attracts monocytes in vitro. Expression of MCP-1 in human islets was recently shown to play an important role in the clinical outcome of islet transplantation in patients with type 1 diabetes [13]. Interestingly, IL-1 $\beta$ has been reported to increase MCP-1 expression in islets $[13,16,17]$. In line with this notion our data showed a concomitant expression of IL-1 $\beta$ and MCP-1 in islets cultured for 2 days. However, in islets cultured for 7 days, high expression of MCP-1 was detected in all islet samples even though no expression of IL-1 $\beta$ could be found.

Expression of MIF was demonstrated in all islet preparations. There seemed to be a correlation between the mRNA levels of MIF and MCP-1 mRNA in all islet preparations analyzed. MIF was originally reported to exert an inhibitory effect on macrophage migration [18], a few years later MIF was shown to have an important role in T-cell activation [19]. MIF expressed in islets is secreted together with insulin and may act as an autocrine factor to promote insulin release. MIF inhibits MCP-1-induced migration of monocytes [20,21]. It may be speculated that the constitutive expression of MIF in the islets acts in concert together with other cytokines/chemokines to promote inflammation and immune activation.
In contrast to hole-organ grafts, islets require a process of angiogenesis for appropriate revascularization after transplantation [22]. Angiogenesis forms in multiple steps regulated by VEGF and other growth factors [23-25]. VEGF is expressed in islets both in vitro and in vivo [26]. Hypoxia is known to increase VEGF expression in many tissues $[27,28]$. The observed high expression of VEGF mRNA in all islet preparations in this study is most likely reflecting the relative hypoxia present during transportation, islet isolation, and in culture.

Hepatocyte growth factor (HGF) may enhance endothelial cell migration into the transplanted islets $[28,29]$. Expression of IL-8, VEGF, and HGF mRNAs was found in islets cultured for 2 days, possibly reflecting a production of other gene products important for the angiogenesis process.

Thymosin $\beta-10, \mathrm{~TB} 10$ is a secretory protein that in human tissue is accompanied by thymosin $\beta 4$, TB4 [30]. TB10 expression is associated with cell growth in proliferating tissue and is a potential tool for diagnosis of several human neoplasias [31]. TB10 expression seems to be modulated by VEGF [32]. The majority of malignant tumors overexpress both VEGF and TB10. For unknown reasons, a similar high expression of both VEGF and TB10 was found in isolated islets. It may be speculated that also this expression is correlated to the relative hypoxia present during islet culture.

In summary, many genes with potent pro-inflammatory capacity were expressed in isolated human islets. Most likely, an expression of these genes at the protein 
level at the time of transplantation would have marked implications on the outcome after transplantation. Our data show that, compared to long-term culture (7-11 days), considerably more genes are expressed in the islets at early stages after isolation. Based on the results presented, it seems advantageous to culture islets before transplantation to reduce expression of these potent inflammatory mediators. In experimental transplantation, it has been repeatedly demonstrated that cultured islets have clear immunological advantages when compared with freshly isolated islets. A practical problem in this respect is to optimize culture conditions for the large number of islets isolated from a human pancreas. It may also be possible to enhance expression of selected genes during culture that may improve islet engraftment, e.g., protective genes (heme oxygenase-1, HO-1, [33]), antiapoptotic genes (Bcl-2, [34]), and immunomodulating genes (IL-10, TGF $\beta[35,36]$ ). To enhance revascularization and subsequent maturation of newly formed capillaries, expression of high levels of VEGF and Ang-1 could be important [37-39]. We foresee the addition of various factors with a potential to regulate both transcription and translation for specific genes that could enhance islet survival in culture and after transplantation.

\section{Acknowledgments}

The authors thank Margaretha Engkvist, Magnus Ståhle, and Lotta Elfman for excellent technical assistance.

\section{References}

[1] A.M. Shapiro, J.R. Lakey, E.A. Ryan, G.S. Korbutt, E. Toth, G.L. Warnock, N.M. Kneteman, R.V. Rajotte, N. Engl. J. Med. 343 (2000) 230-238.

[2] L. Moberg, H. Johansson, A. Lukinius, C. Berne, A. Foss, R Kallen, O. Ostraat, K. Salmela, A. Tibell, G. Tufveson, G. Elgue, K. Nilsson Ekdahl, O. Korsgren, B. Nilsson, Lancet 360 (2000) 2039-2045.

[3] A. Shalev, C.A. Pise-Masison, M. Radonovich, S.C. Hoffmann, B Hirshberg, J.N. Brady, D.M. Harlan, Endocrinology 143 (2000) 3695-3698.

[4] D. Pipeleers, B. Keymeulen, L. Chatenoud, C. Hendrieckx, Z. Ling, C. Mathieu, B. Roep, D. Ysebaert, Ann. N. Y. Acad. Sci. 958 (2000) 69-76.

[5] R. Barry, M. Tadayyon, I.C. Green, Biochem. Biophys. Res Commun. 298 (2002) 350-356.

[6] C. Ricordi, P.E. Lacy, E.H. Finke, B.J. Olack, D.W. Scharp, Diabetes 37 (1998) 413-420.

[7] H. Brandhorst, D. Brandhorst, M.D. Brendel, B.J. Hering, R.G Bretzel, Cell Transplant 7 (1998) 489-495.

[8] J.R. Lakey, G.L. Warnock, A.M. Shapiro, G.S. Korbutt, Z. Ao, N.M. Kneteman, R.V. Rajotte, Cell Transplant 8 (1999) 285-292.

[9] L. Wennberg, Z. Song, W. Bennet, J. Zhang, S. Nava, B. Sundberg, S. Bari, C.G. Groth, O. Korsgren, Transplantation 71 (2001) 1024-1033.

[10] D.S. Wilson, S. Nock, Angew. Chem. Int. Ed. Engl. 42 (2003) 494-500.

[11] G.C. Webb, M.S. Akbar, C. Zhao, D.F. Steiner, Proc. Natl. Acad. Sci. USA 97 (2000) 5773-5778.
[12] Y. Zimmer, D. Milo-Landesman, A. Svetlanov, S. Efrat, FEBS Lett. 457 (1999) 65-70.

[13] L. Piemonti, B.E. Leone, R. Nano, A. Saccani, P. Monti, P. Maffi, G. Bianchi, A. Sica, G. Peri, R. Melzi, L. Aldrighetti, A. Secchi, V. Di Carlo, P. Allavena, F. Bertuzzi, Diabetes 51 (2002) 55-65.

[14] A.K. Andersson, S. Sandler, J. Pineal. Res. 30 (2001) 157-165.

[15] T. Rydgren, S. Sandler, Eur. J. Endocrinol. 147 (2002) 543-551.

[16] M.C. Chen, F. Schuit, D.L. Eizirik, Diabetologia 42 (1999) 11991203.

[17] M.C. Chen, P. Proost, C. Gysemans, C. Mathieu, D.L. Eizirik, Diabetologia 44 (2001) 325-332.

[18] G. Waeber, T. Calandra, R. Roduit, J.A. Haefliger, C. Bonny, N. Thompson, B. Thorens, E. Temler, A. Meinhardt, M. Bacher, C.N. Metz, P. Nicod, R. Bucala, Proc. Natl. Acad. Sci. USA 94 (1997) 4782-4787.

[19] M. Bacher, C.N. Metz, T. Calandra, K. Mayer, J. Chesney, M. Lohoff, D. Gemsa, T. Donnelly, R. Bucala, Proc. Natl. Acad. Sci. USA 93 (1996) 7849-7854.

[20] A. Hermanowski-Vosatka, S.S. Mundt, J.M. Ayala, S. Goyal, W.A. Hanlon, R.M. Czerwinski, S.D. Wright, C.P. Whitman, Biochemistry 38 (1999) 12841-12849.

[21] M. Lind, M.C. Trindade, Y. Nakashima, D.J. Schurman, S.B. Goodman, L. Smith, J. Biomed. Mater. Res. 48 (1999) 246250.

[22] M.D. Menger, J. Yamauchi, B. Vollmar, World J. Surg. 25 (2001) $509-515$.

[23] N. Ferrara, T. Davis-Smyth, Endocr. Rev. 18 (1997) 4-25.

[24] G. Neufeld, T. Cohen, S. Gengrinovitch, Z. Poltorak, FASEB J. 13 (1999) 9-22.

[25] P. Carmeliet, D. Collen, Kidney Int. 53 (1998) 1519-1549.

[26] M. Kuroda, T. Oka, Y. Oka, T. Yamochi, K. Ohtsubo, S. Mori, T. Watanabe, R. Machinami, S. Ohnishi, J. Clin. Endocrinol. Metab. 80 (1995) 3196-3200.

[27] D.L. Gorden, S.J. Mandriota, R. Montesano, L. Orci, M.S. Pepper, Transplantation 63 (1997) 436-443.

[28] B. Vasir, J.C. Jonas, G.M. Steil, J. Hollister-Lock, W. Hasenkamp, A. Sharma, S. Bonner-Weir, G.C. Weir, Transplantation 71 (2001) 924-935

[29] B. Vasir, P. Reitz, G. Xu, A. Sharma, S. Bonner-Weir, G.C. Weir, Diabetologia 43 (2000) 763-772.

[30] I. Vassiliadou, L. Leondiadis, N. Ferderigos, D.S. Ithakissios, G.P. Evangelatos, E. Livaniou, Peptides 20 (1999) 411-414.

[31] G. Santelli, D. Califano, G. Chiappetta, M.T. Vento, P.C. Bartoli, F. Zullo, F. Trapasso, G. Viglietto, A. Fusco, Am. J. Pathol. 155 (1999) 799-804

[32] E. Vasile, Y. Tomita, L.F. Brown, O. Kocher, H.F. Dvorak, FASEB J. 15 (2001) 458-466.

[33] M. Katori, R.W. Busuttil, J.W. Kupiec-Weglinski, Transplantation 74 (2002) 905-912.

[34] J.L. Contreras, C.A. Smyth, G. Bilbao, C. Eckstein, C.J. Young, J.A. Thompson, D.T. Curiel, D.E. Eckhoff, Transplant Int. (2003).

[35] Y.C. Zhang, A. Pileggi, A. Agarwal, R.D. Molano, M. Powers, T. Brusko, C. Wasserfall, K. Goudy, E. Zahr, R. Poggioli, M. ScottJorgensen, M. Campbell-Thompson, J.M. Crawford, H. Nick, T. Flotte, T.M. Ellis, C. Ricordi, L. Inverardi, M.A. Atkinson, Diabetes 52 (2003) 708-716.

[36] A.M. Shapiro, W.L. Suarez-Pinzon, R. Power, A. Rabinovitch, Diabetologia 45 (2002) 224-230.

[37] T. Linn, K. Schneider, H.P. Hammes, K.T. Preissner, H Brandhorst, E. Morgenstern, F. Kiefer, R.G. Bretzel, FASEB J. 17 (2003) 881-883.

[38] M.K. Reimer, S.P. Mokshagundam, K. Wyler, F. Sundler, B. Ahren, J.I. Stagner, Pancreas 26 (2003) 392-397.

[39] O. Stoeltzing, S.A. Ahmad, W. Liu, M.F. McCarty, J.S. Wey, A.A. Parikh, F. Fan, N. Reinmuth, M. Kawaguchi, C.D. Bucana, L.M. Ellis, Cancer Res. 63 (2003) 3370-3377. 